\title{
Synergistic enhancement of matrix metalloproteinase-9 expression and pro-inflammatory cytokines by influenza virus infection and oxidized-LDL treatment in human endothelial cells
}

\author{
YUN WU ${ }^{1-3}$ and $\mathrm{HE} \mathrm{HUANG}^{1-3}$ \\ ${ }^{1}$ Department of Cardiovascular Medicine, Renmin Hospital of Wuhan University; ${ }^{2}$ Cardiovascular Research Institute, \\ Wuhan University; ${ }^{3}$ Key Laboratory of Cardiovascular Disease in Hubei, Wuhan, Hubei 430060, P.R. China
}

Received July 14, 2016; Accepted April 21, 2017

DOI: $10.3892 / e t m .2017 .5099$

\begin{abstract}
Oxidized low-density lipoprotein (oxLDL) has been reported to contribute to the development and progression of atherosclerosis, which is also stimulated by viral infections, such as influenza. However, the mechanism underlining the promotion of atherosclerosis by both risk factors remains unclear. In the present study, we investigated the expression of matrix metalloproteinase-9 (MMP-9), which is one of key mediators of atherosclerosis progression, in oxLDL-treated human umbilical vein endothelial cells (HUVEC)-C cells The infection efficiency of H1N1 pdm2009 influenza virus in the HUVEC-C cells was subsequently examined, and the expression of MMP-9 and proinflammatory cytokines, including tumor necrosis factor (TNF)- $\alpha$, interleukin (IL)- $1 \beta$ and IL-6, were determined in the virus-infected HUVEC-C cells, with or without oxLDL treatment. Results demonstrated that oxLDL treatment with 10,20 or $50 \mu \mathrm{g} / \mathrm{ml}$ markedly upregulated MMP-9 expression at the mRNA and protein levels. H1N1 pdm2009 influenza virus efficiently infected the HUVEC-C cells and significantly promoted the expression of MMP-9, TNF- $\alpha$, IL-1 $\beta$ and IL-6, synergistically with the oxLDL treatment. Taken together, these results demonstrated for the first time that oxidized-LDL treatment and influenza virus infection synergistically enhance the expression of MMP-9 and proinflammatory cytokines in human endothelial cells, suggesting that both factors are potent stimulators in atherosclerotic impairment to endothelial cells.
\end{abstract}

Correspondence to: Dr He Huang, Department of Cardiovascular Medicine, Renmin Hospital of Wuhan University, 99 Zhangzhidong Road (238 Jiefang Road), Wuchang, Wuhan, Hubei 430060, P.R. China

E-mail: he_huang_wuhan@sina.com

Key words: influenza virus, endothelial, human umbilical vein endothelial cells, oxidized low density lipoprotein, matrix metalloproteinase-9, proinflammatory cytokines

\section{Introduction}

Oxidized low-density lipoprotein (oxLDL) reportedly contributes to the development and progression of atherosclerosis (1) and is used as a biomarker of atherosclerosis and cardiovascular risk in circulation (2). High circulating oxLDL directly exerts oxidative stress (3), or even induces apoptosis (4), in smooth muscle cells and endothelial cells. oxLDL also promotes the production or circulating long-term proinflammatory cytokines (5) and indirectly impairs the function of vascularity. To date, multiple markers, such as caspases (6) and lectin-like oxidized-low density lipoprotein receptor-1 (4), have been demonstrated to mediate the oxLDL-induced apoptotic cascade in endothelial cells. Therefore, oxLDL is a key contributor to the endothelial cell damage that initiates atherosclerosis.

During the migration of smooth muscle cells (SMCs) and the plaque rupture in atherosclerosis, matrix metalloproteinases (MMPs) have been recognized to catalyze the degradation of fibrous cap components such as collagens, elastin, fibronectin and proteoglycans (7-9), and thus contribute to the vulnerability of atherosclerotic plaques. Among the more than 20 types of MMPs (10), MMP-1, -2, -3, -7, -8, -9, -13, and -14 have been reported to be increased at atherosclerotic lesions in human and animal models (9,11-14). MMP-1 and MMP-14 predominantly localize in SMCs $(15,16)$ and macrophages $(13)$, whereas MMP-8 and -13 are produced from neutrophils (14) and macrophages (13), respectively. MMP-9 levels are upregulated in human monocyte-derived macrophages (17); however, little is known about the contribution of oxLDL to the production of MMP-9 in endothelial cells.

With the exception of oxLDL, infection also contributes to the formation of atherosclerosis. In particular, infection with viruses, with such agents as human cytomegalovirus (HCMV) $(18,19)$, herpes simplex viruses (HSV) (20) and influenza virus $(21,22)$ have been identified to accelerate atherosclerosis. The promoted vascular inflammation $(23,24)$ impairs the vascularity and causes endothelial cell (EC) dysfunction $(25,26)$ during viral infection. Serological studies support the association between infection with HCMV, human immunodeficiency virus, HSV $(27,28)$ and influenza virus $(22)$ with atherosclerosis. In particular, animal and human studies 
have confirmed that prothrombotic and pro-inflammatory effects are caused by influenza infection (29). However, there are minimal reports on the orchestrated molecular signals that are promoted by influenza virus infection during atherosclerosis, particularly, about the promotion of MMP by the viral infection in the background of atherosclerosis.

In the present study, we aimed to determine whether MMP-9 was promoted by infection with H1N1 pdm2009 influenza virus and by treatment with oxLDL in human umbilical vein endothelial cells (HUVECs). Subsequently, we investigated the influence of viral infection and oxLDL treatment on the production of proinflammatory cytokines and cellular viability in HUVECs. The present study confirmed the synergistic enhancement of MMP-9 expression and cellular viability reduction by influenza virus infection and oxidized-LDL treatment in human endothelial cells, implying the contribution of influenza virus infection to the oxLDL-induced impairment to endothelial cells.

\section{Materials and methods}

Reagents and cell culture. OxLDL was purchased from Biomedical Technologies Inc., (Stoughton, MA, USA) and resolved in F-12K medium with a concentration of $1 \mathrm{mg} / \mathrm{ml}$. The human umbilical vein endothelial HUVEC-C cell line (passage 3) was purchased from American Type Culture Collection (Manassas, VA, USA) and limitedly propagated (less than passage 14) in F-12K medium (Kaighn's Modification of Ham's F-12 Medium; Thermo Fisher Scientific, Inc., Waltham, MA, USA) supplemented with $10 \%$ fetal bovine serum (FBS; Invitrogen; Thermo Fisher Scientific, Inc.) and $1 \%$ penicillin/streptomycin (Sigma-Aldrich; Merck $\mathrm{KGaA}$, Darmstadt, Germany) at $37^{\circ} \mathrm{C}$ under $5 \% \mathrm{CO}_{2}, \mathrm{~F}-12 \mathrm{~K}$ medium supplemented with $0.3 \%$ bovine serum albumin (BSA), $1 \mathrm{mg} / \mathrm{ml}$ tosyl phenylalanyl chloromethyl ketone (TPCK)-treated trypsin (both from Sigma-Aldrich; Merck $\mathrm{KGaA}$ ) and $1 \%$ penicillin/streptomycin were used for H1N1 pdm2009 influenza virus infection (Beijing Wantai Biological Pharmacy Enterprise Co., Ltd., Beijing, China). For the oxLDL treatment, $\sim 90 \%$ confluent HUVEC-C cells were treated with $0,10,20$ or $50 \mu \mathrm{g} / \mathrm{ml}$ oxLDL for $0-48 \mathrm{~h}$. Following oxLDL incubation, cells were lysed for the mRNA expression analysis or for the western blotting analysis.

Virus infection and plaque forming assay. For viral infection, $90 \%$ confluent HUVEC-C cells were infected with serially-diluted H1N1 pdm2009 influenza virus of 0.001 , $0.01,1$ or 5 multiplicity of infection (MOI) for $45 \mathrm{~min}$ at $35^{\circ} \mathrm{C}$. Subsequently, the viral supernatant was removed and cells were replenished with F-12K medium supplemented with $0.3 \%$ BSA, $1 \mathrm{mg} / \mathrm{ml}$ TPCK-treated trypsin and $1 \%$ penicillin/streptomycin. For the virus replication assay, cells were inoculated for another 12,24 or $48 \mathrm{~h}$, and the supernatant was tittered with plaque forming assay. For the cell viability or apoptosis assay, cells were inoculated for another 12 or $24 \mathrm{~h}$, and were subjected to methyl thiazolyl tetrazoliym assay (MTT assay). For the plaque formation assay, confluent monolayer HUVEC-C cells were inoculated with $0,0.001$, 0.01 , or $0.1 \mathrm{MOI} \mathrm{H} 1 \mathrm{~N} 1 \mathrm{pdm} 2009$ influenza virus at $35^{\circ} \mathrm{C}$ for $45 \mathrm{~min}$, and were overlaid with $1 \%$ hypo-temperature-solved agarose containing $0.3 \% \mathrm{BSA}, 1 \mathrm{mg} / \mathrm{ml}$ TPCK-treated trypsin and $1 \%$ penicillin/streptomycin. After 3 days of inoculation at $35^{\circ} \mathrm{C}$, cells were fixed with $4 \%$ formaldehyde for $20 \mathrm{~min}$ at $35^{\circ} \mathrm{C}$ and stained with $1 \%$ crystal violet solution at $35^{\circ} \mathrm{C}$ overnight.

RNA isolation and reverse transcription-quantitative polymerase chain reaction ( $R T-q P C R)$. Total cellular RNA from HUVEC-C cells was isolated using TRIzol reagent (Thermo Fisher Scientific, Inc.) and supplemented with RNasin Plus RNase Inhibitor (Promega Corp., Madison, WI, USA). The cDNA was synthesized using $1 \mu \mathrm{g}$ of total RNA using high capacity cDNA reverse transcription kit (Applied Biosystems, Thermo Fisher Scientific, Inc.). RT-qPCR was performed using a Takara One Step RT-PCR kit (Takara Biotechnology, Tokyo, Japan). The cDNA template (50 ng) was amplified using Inventoried TaqMan Gene Expression Assay products. The primers used were as follows: MMP-9 forward, 5'-AACCCT GGTCACCGGACTTC-3' and reverse, 5'-CACCCGGTTGTG GAAACTCAC-3'; TNF- $\alpha$ forward, 5'-AGAACTCCAGGC GGTGTCT-3' and reverse, 5'-A-GAA-CTCCAGGCGGTG TCT-3'; IL-1 $\beta$ forward, 5'TCCAGCTACGAATCTCCGAC3' and reverse, 5'TCCAGCTACGAATCTCCGAC3'; $\beta$-actin forward, 5'-ATATCGCTGCGCTCGTCGTC-3' and reverse, 5'-GCATCGGAACCGCTCATTGC-3'; IL-6 forward, 5'AGT CCTGATCCAGTTCCTGC3' and reverse, 5'CATTTGTGG TTGGGTCAGGG3'. PCR was performed under the following conditions: $95^{\circ} \mathrm{C}$ for $30 \mathrm{sec}, 95^{\circ} \mathrm{C}$ for $15 \mathrm{sec}, 60^{\circ} \mathrm{C}$ for $30 \mathrm{sec}$, and $68^{\circ} \mathrm{C}$ for $30 \mathrm{sec}$ for 40 cycles. Relative quantification was determined using the $2^{-\Delta \Delta \mathrm{Cq}}$ method using $\beta$-actin as reference genes (30).

Cell viability assay. Cell viability was evaluated by MTT assay (Invitrogen; Thermo Fisher Scientific, Inc.). Briefly, 90\% confluent HUVEC-C cells following oxLDL treatment, H1N1 PDM2009 virus infection or both were incubated with $50 \mu \mathrm{l}$ MTT solution at $37^{\circ} \mathrm{C}$ for $2 \mathrm{~h}$, and were dissolved completely by $150 \mu \mathrm{l}$ DMSO at room temperature. Optical density was subsequently measured at $570 \mathrm{~nm}$ using a spectrophotometer (Bio-Rad Laboratories, Inc., Hercules, CA, USA).

Western blot assay. Following treatment, HUVEC-C cells were lysed with a NE-PER Nuclear and Cytoplasmic Extraction Reagents kit (Pierce; Thermo Fisher Scientific, Inc.), and the cellular lysate was supplemented with a protease inhibitor cocktail (Roche Diagnostics GmbH, Wetzlar, Germany), following centrifugation at 13,400 x g for $15 \mathrm{~min}$. Proteins $(25 \mu \mathrm{l})$ were separated by $12 \%$ SDS-PAGE and transferred to a nitrocellulose membrane (Millipore, Bedford, MA, USA). Following blocking with $2 \% \mathrm{BSA}$ at $4^{\circ} \mathrm{C}$ overnight, the membrane was incubated with rabbit polyclone antibodies against MMP-9 (cat. no. 444278-500UG; 1:400; Merck KGaA) or $\beta$-actin (cat. no. bs-0061R; 1:2,000; Beijing Biosynthesis Biotechnology Co., Ltd., Beijing, China) for $1 \mathrm{~h}$ at $37^{\circ} \mathrm{C}$. The membrane was washed with TBST for $3 \mathrm{~min}$ and incubated with goat anti-rabbit IgG secondary antibody conjugated to horseradish peroxidase (cat. no. 1662408ED; 1:500; Bio-Rad Laboratories, Inc.) for $40 \mathrm{~min}$ at room temperature and an enhanced chemiluminescence detection system (GE Healthcare Life Sciences, Little Chalfont, UK) was used for target protein band detection. 
A

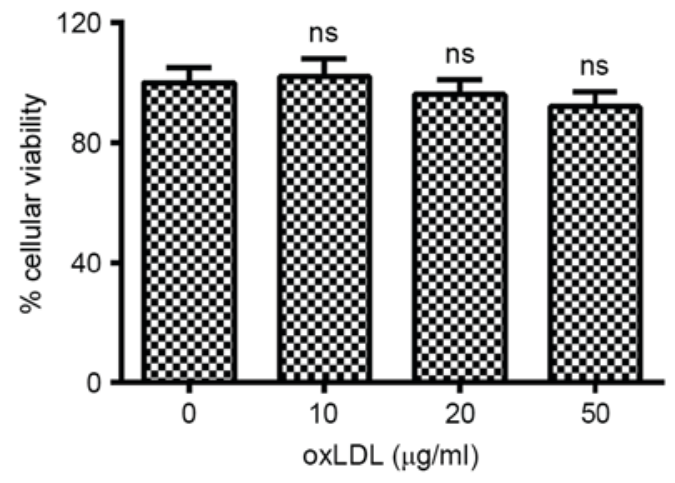

C
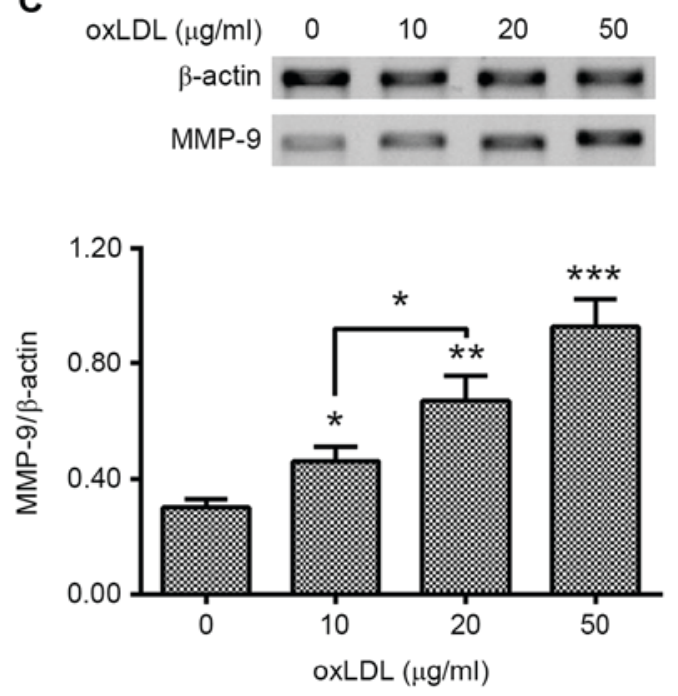

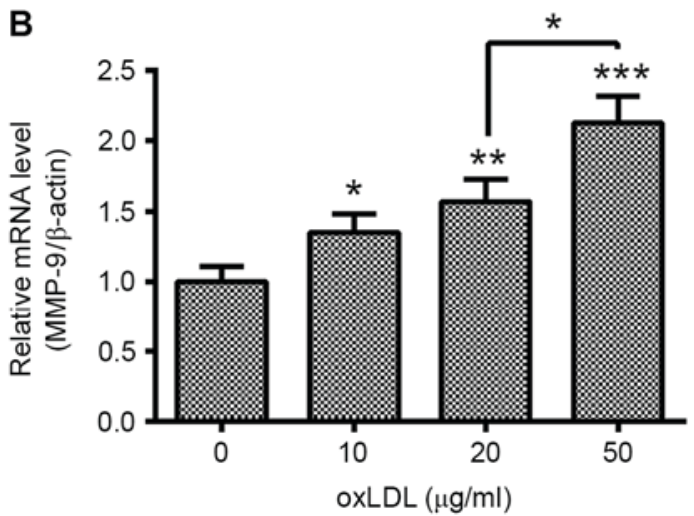

D

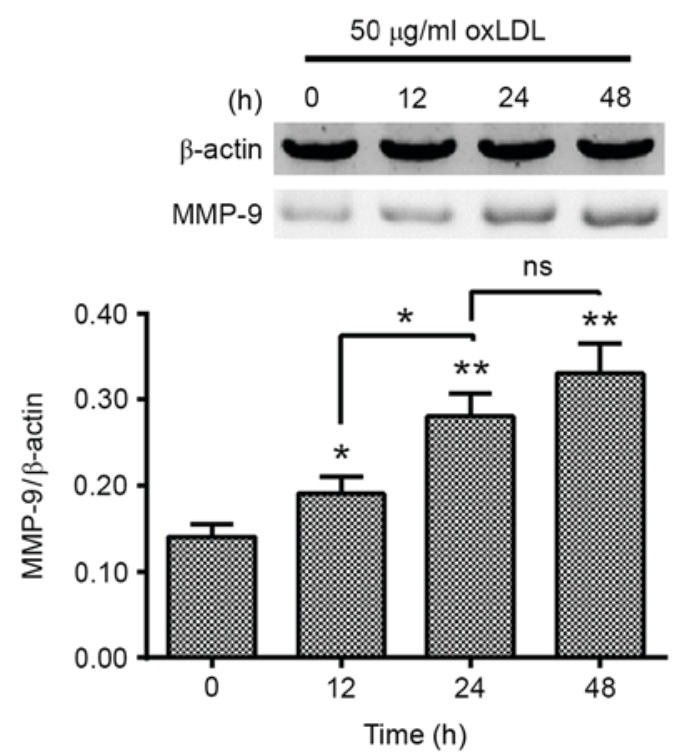

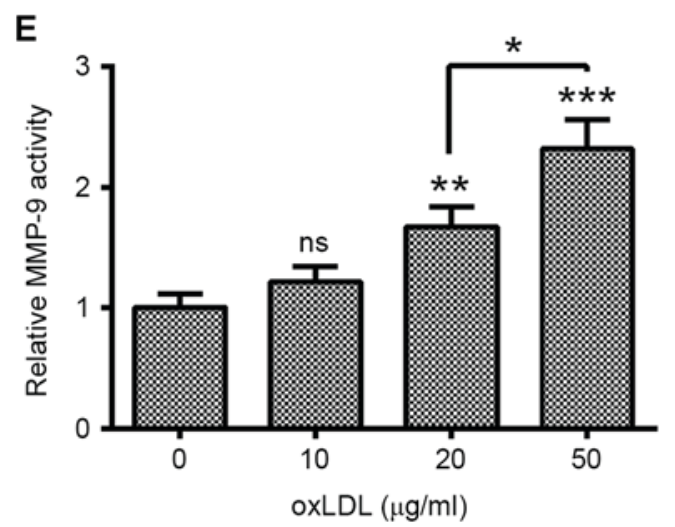

Figure 1. oxLDL treatment promotes MMP-9 expression in human endothelial HUVEC-C cells. (A) MTT assay of HUVEC-C cells following treatment with 0, 10, 20 or $50 \mu \mathrm{g} / \mathrm{ml}$ oxLDL for $24 \mathrm{~h}$. (B) mRNA levels of MMP-9 in HUVEC-C cells treated with $0,10,20 \mathrm{or} 50 \mu \mathrm{g} / \mathrm{ml}$ oxLDL for $12 \mathrm{~h}$. (C) Western blot assay of cytosolic MMP-9 in HUVEC-C cells treated with 0, 10, 20 or $50 \mu \mathrm{g} / \mathrm{ml}$ oxLDL for $24 \mathrm{~h}$. (D) Western blot assay of cytosolic MMP-9 in HUVEC-C cells treated with $50 \mu \mathrm{g} / \mathrm{ml}$ oxLDL for 0, 12, 24 or $48 \mathrm{~h}$. (E) MMP-9 activity in HUVEC-C cells treated with 0, 10, 20 or $50 \mu \mathrm{g} / \mathrm{ml}$ oxLDL for $24 \mathrm{~h}$. Data are presented as the average of triplicate results. ${ }^{*} \mathrm{P}<0.05,{ }^{* *} \mathrm{P}<0.01$ and ${ }^{* * *} \mathrm{P}<0.001 \mathrm{vs} .0 \mu \mathrm{g} / \mathrm{ml}$ oxLDL or $0 \mathrm{~h}$. NS, not significant; HUVEC, human umbilical vein endothelial cells; oxLDL, oxidized low density lipoprotein; MMP, matrix metalloproteinase.

\section{Results}

oxLDL promotes the expression of MMP-9 in HUVEC-C cells. To investigate the regulation of the induction of MMP-9 by oxLDL treatment in HUVEC-C cells, HUVEC-C cells were treated with $0,10,20$ or $50 \mu \mathrm{g} / \mathrm{ml}$ oxLDL for $0,12,24$ or $48 \mathrm{~h}$. Cellular viability and the expression of MMP-9 in the oxLDL-treated HUVEC-C cells were examined. As indicated in Fig. 1A, oxLDL treatment with $0,10,20$ or $50 \mu \mathrm{g} / \mathrm{ml} \mathrm{did}$ not significantly regulate the cellular viability of HUVEC-C cells. However, MMP-9 expression was markedly promoted by oxLDL treatment. MMP-9 mRNA levels were significantly higher in HUVEC-C cells treated with $10(\mathrm{P}<0.05), 20(\mathrm{P}<0.01)$ or $50(\mathrm{P}<0.001) \mu \mathrm{g} / \mathrm{ml}$ oxLDL for $12 \mathrm{~h}$, with a dose-dependent increase noted between 20 and $50 \mu \mathrm{g} / \mathrm{ml}$ oxLDL $(\mathrm{P}<0.05$; Fig. 1B). Western blotting results confirmed the promotion of 


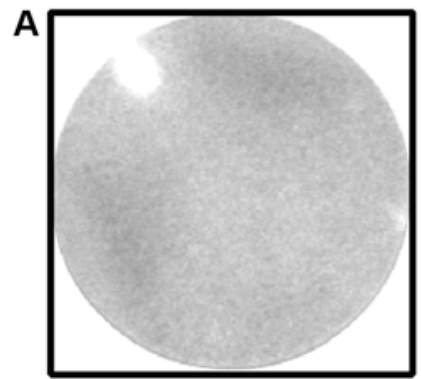

$\mathrm{MOI}$

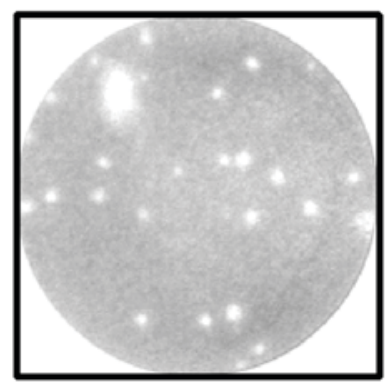

0.001

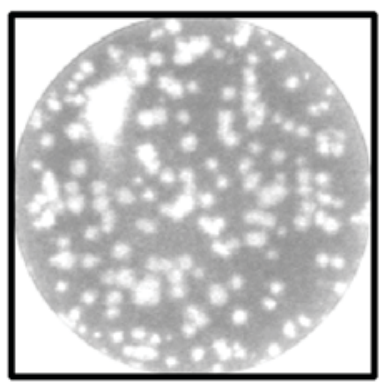

0.01

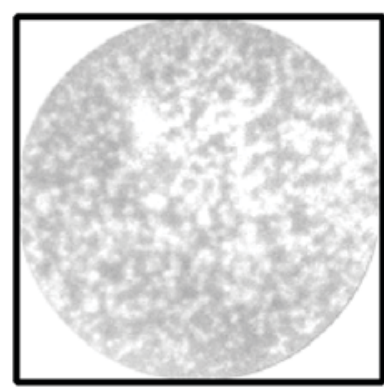

0.1
B

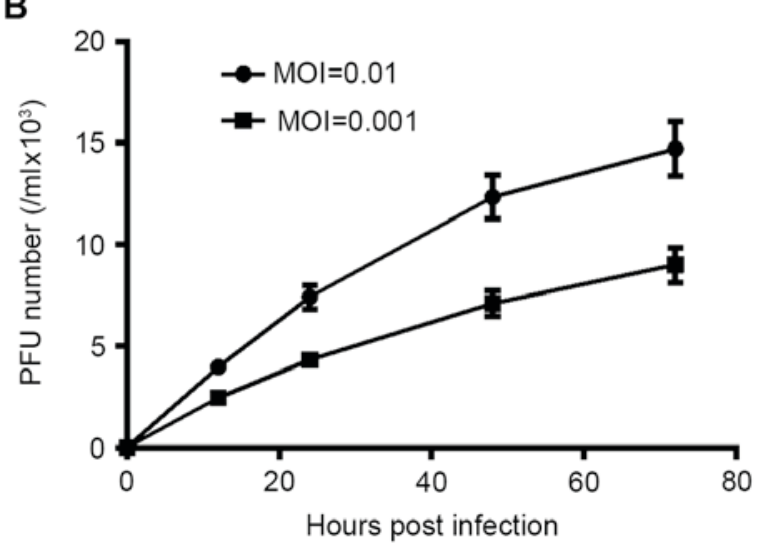

C

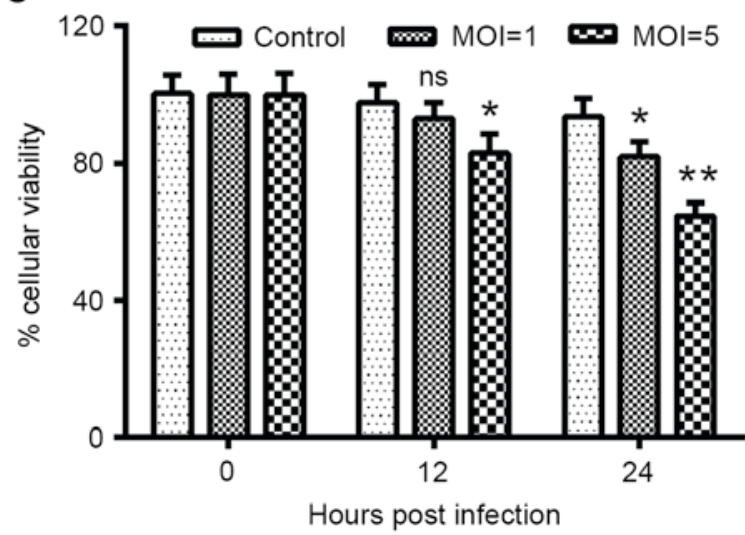

Figure 2. H1N1 PDM2009 virus infects and forms plaques in human endothelial HUVEC-C cells. (A) Plaque forming assay in HUVEC-C cells, which were infected with $0,0.001,0.01$, or 0.1 MOI H1N1 PDM2009 virus. (B) Growth curve of H1N1 PDM2009 virus in HUVEC-C cells, with a MOI of 0.001 or 0.01. (C) MTT assay for the viability of HUVEC-C cells, following infection with 1 or 5 MOI H1N1 PDM2009 virus for 0, 12 or 24 h. Experiments were independently repeated in triplicate. ${ }^{*} \mathrm{P}<0.05$ and ${ }^{* *} \mathrm{P}<0.01$ vs. $0 \mathrm{~h}$ post-infection. HUVEC, human umbilical vein endothelial cells; NS, not significant; oxLDL, oxidized low density lipoprotein; MOI, multiplicity of infection.

MMP-9 at a protein level $(\mathrm{P}<0.05, \mathrm{P}<0.01$ and $\mathrm{P}<0.001$ for 10 , 20 and $50 \mu \mathrm{g} / \mathrm{ml}$, respectively; Fig. $1 \mathrm{C})$, with a dose-dependent increase noted between 10 and $20 \mu \mathrm{g} / \mathrm{ml}$ oxLDL $(\mathrm{P}<0.05)$. MMP-9 promotion was also time-dependent, the MMP-9 in protein level was significantly different between 12 and $48 \mathrm{~h}$ post-treatment with $50 \mu \mathrm{g} / \mathrm{ml}$ oxLDL $(\mathrm{P}<0.05$ and $\mathrm{P}<0.01$, respectively; Fig. 1D). In addition, MMP-9 activity was also examined in the oxLDL-treated HUVEC-C cells. As shown in Fig. 1E, MMP-9 activity was markedly promoted by the oxLDL treatment with 20 or $50 \mu \mathrm{g} / \mathrm{ml}$. These findings suggest that treatment with oxLDL promoted the expression of MMP-9 in human endothelial HUVEC-C cells.

H1N1 PDM2009 influenza virus infects and replicates in HUVEC-C cells. To investigate the influence of influenza virus infection on OxLDL-promoted MMP-9 expression in endothelial cells, we determined the infection efficiency of H1N1 PDM2009 influenza virus in HUVEC-C cells. First, we determined the plaque forming capacity of H1N1 PDM2009 virus in HUVEC-C cells. Fig. 2A demonstrated that inoculation with $0.001,0.01$ or 0.1 MOI H1N1 PDM2009 promoted plaque forming in HUVEC-C cells; and the plaque number positively correlated with the MOI of H1N1 PDM2009. The growth curve of H1N1 PDM2009 influenza virus was also determined, which indicated that either a MOI of 0.001 or 0.01 H1N1 PDM2009 influenza virus replicated efficiently in HUVEC-C cells, or the replication continued from $48 \mathrm{~h}$ post-infection (Fig. 2B). In addition, the viability of HUVEC-C cells following infection with 5 MOI H1N1 PDM2009 was significantly reduced at 12 or $24 \mathrm{~h}$ post-infection, as compared with $0 \mathrm{~h}(\mathrm{P}<0.05$ and $\mathrm{P}<0.01$, respectively; Fig. 2C). Similarly, the viability of HUVEC-C cells following infection with 1 MOI H1N1 PDM2009 was significantly reduced at $24 \mathrm{~h}$ post-infection, as compared with $0 \mathrm{~h}(\mathrm{P}<0.05)$. Therefore, the H1N1 PDM2009 influenza viruses infected and replicated efficiently in the human endothelial HUVEC-C cells.

HIN1 PDM2009 virus infection synergistically enhances oxLDL-promoted MMP-9 in HUVEC-C cells. In order to explore the influence of H1N1 PDM2009 virus infection on oxLDL-induced MMP-9 expression in HUVEC-C cells, we examined the influence of H1N1 PDM2009 virus infection and oxLDL treatment on the viability of HUVEC-C cells. As indicated in Fig. 3A, the cellular viability reduction was more significant in the oxLDL-treated $(20 \mu \mathrm{g} / \mathrm{ml})$ HUVEC-C cells, which were also infected with 1 MOI H1N1 PDM2009 virus at 12 or $24 \mathrm{~h}$ post-treatment/infection $(\mathrm{P}<0.05$ and $\mathrm{P}<0.01$, respectively; Fig. 3A). MMP-9 expression was markedly higher in the oxLDL-treated and virus-infected HUVEC-C cells than in the either oxLDL-treated or virus-infected HUVEC-C cells $(\mathrm{P}<0.05$ and $\mathrm{P}<0.01$, respectively; Fig. 3B). This synergistic effect on MMP-9 promotion was confirmed at the protein level via western blotting in the HUVEC-C cells $(\mathrm{P}<0.01$; Fig. 3C). In addition, MMP-9 activity was also synergistically upregulated by oxLDL treatment and H1N1 PDM2009 virus infection $(\mathrm{P}<0.01$; Fig. $3 \mathrm{D})$. These results indicate that 
A

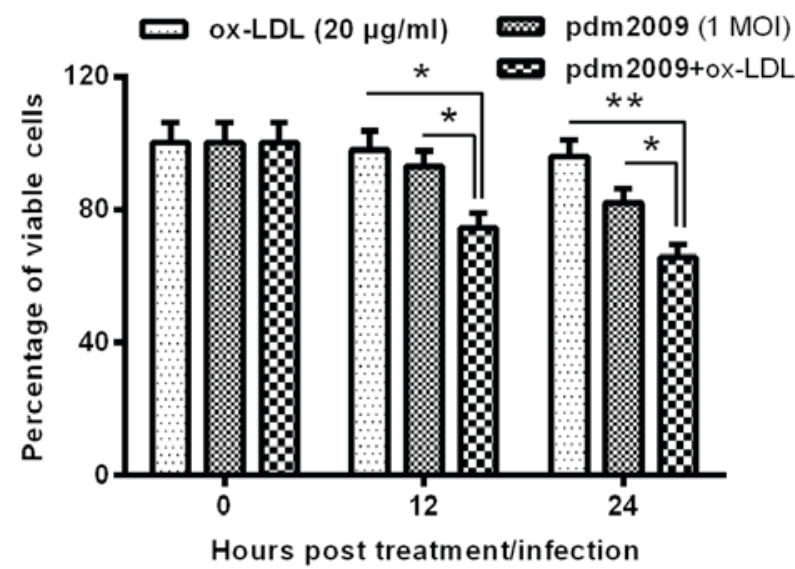

C

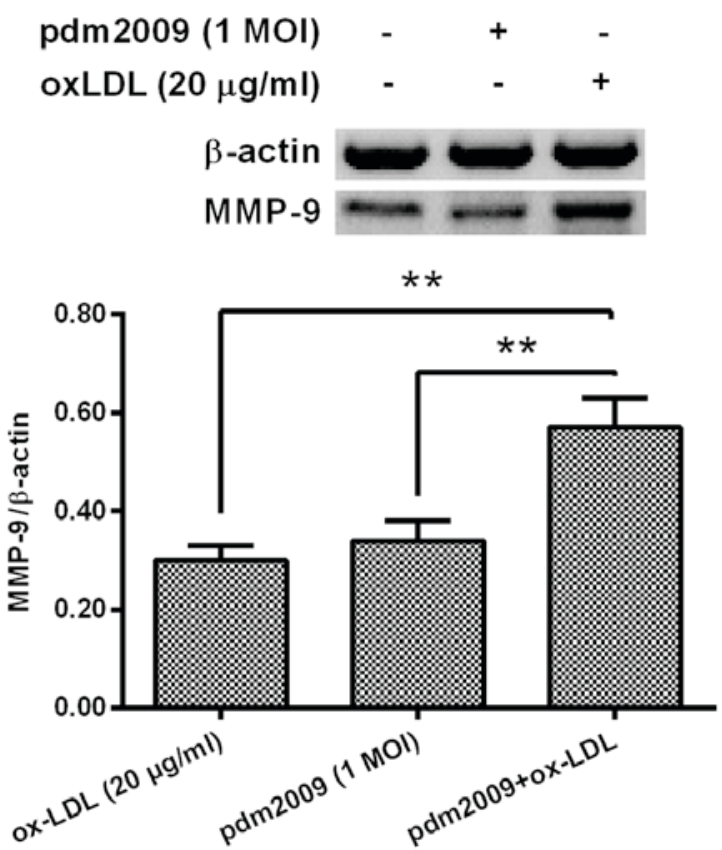

B

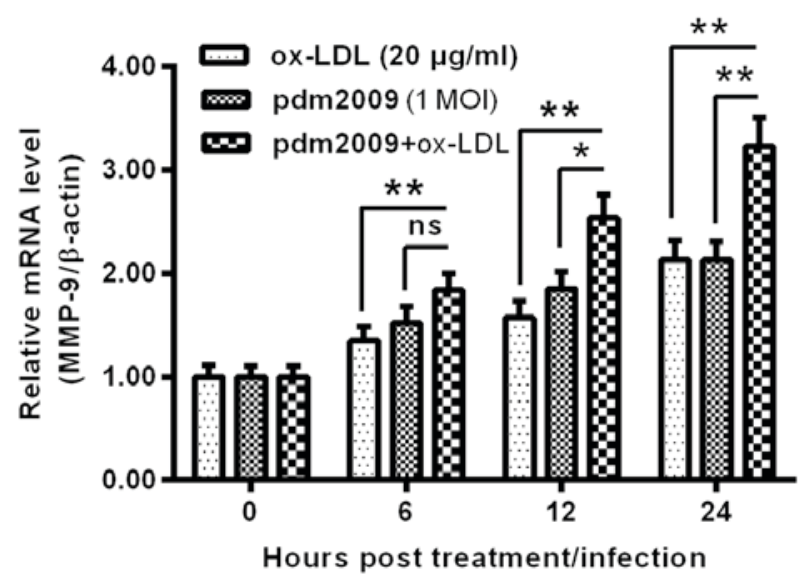

D

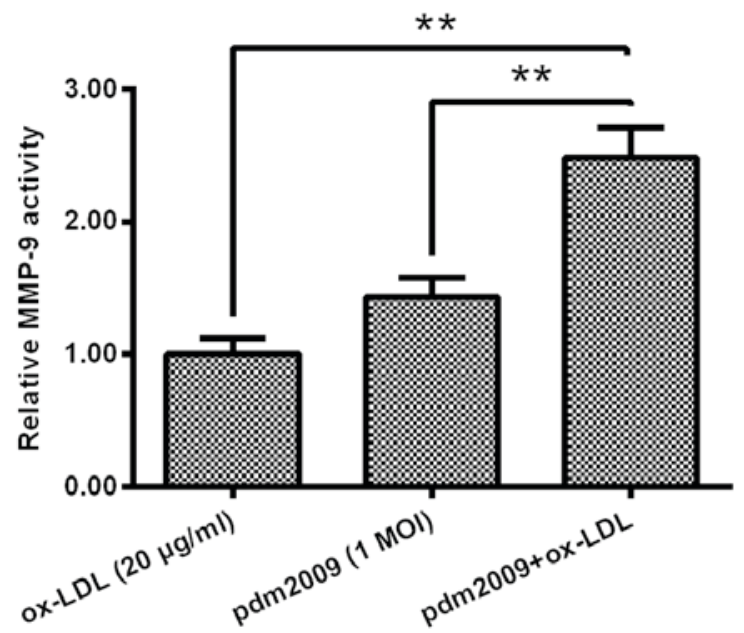

Figure 3. H1N1 PDM2009 virus infection synergistically enhances oxLDL-promoted MMP-9 in human endothelial HUVEC-C cells. (A) MTT assay of HUVEC-C cells following treatment with $20 \mu \mathrm{g} / \mathrm{ml}$ oxLDL and/or following infection with 1 MOI H1N1 PDM2009 virus for 0, 12 or $24 \mathrm{~h}$. (B) Relative mRNA levels of MMP-9 in HUVEC-C cells treated with $20 \mu \mathrm{g} / \mathrm{ml}$ oxLDL and/or infected with 1 MOI H1N1 PDM2009 virus for 0, 6, 12 or $24 \mathrm{~h}$. Western blot analysis of (C) MMP-9 protein expression and (D) MMP-9 activity in HUVEC-C cells following treatment with $20 \mu \mathrm{g} / \mathrm{ml}$ oxLDL and/or following infection with 1 MOI H1N1 PDM2009 virus for $24 \mathrm{~h}$. Experiments were independently repeated in triplicate. " $\mathrm{P}<0.05$ and ${ }^{* *} \mathrm{P}<0.01$. HUVEC, human umbilical vein endothelial cells; NS, not significant; oxLDL, oxidized low density lipoprotein; MMP, matrix metalloproteinase; MOI, multiplicity of infection.

the H1N1 PDM2009 virus infection synergistically enhanced oxLDL-induced MMP-9 expression in HUVEC-C cells.

H1N1 PDM2009 virus and oxLDL synergistically promote pro-inflammatory cytokines in HUVEC-C cells. To investigate whether oxLDL treatment and H1N1 PDM2009 virus infection synergistically induced pro-inflammatory cytokines in the endothelial HUVEC-C cells, we examined the expression levels of TNF- $\alpha$, IL-1 $\beta$ and IL- 6 in HUVEC-C cells, following treatment with $20 \mu \mathrm{g} / \mathrm{ml}$ oxLDL, infection with 1 MOI H1N1 PDM2009 virus or with both treatments. mRNA levels of TNF- $\alpha$ were markedly promoted by either treatment with $20 \mu \mathrm{g} / \mathrm{ml}$ oxLDL or by infection with 1 MOI H1N1 PDM2009 virus $(\mathrm{P}<0.05$ and $\mathrm{P}<0.01$, respectively; Fig. $4 \mathrm{~A})$. Such promotion of TNF- $\alpha$ was more notable in the HUVEC-C cells subjected to both $20 \mu \mathrm{g} / \mathrm{ml}$ oxLDL treatment and infection with 1 MOI H1N1 PDM2009 virus ( $\mathrm{P}<0.05)$. Synergistic promotion by oxLDL treatment and virus infection was also recognized in IL-1 $\beta$ and IL-6. mRNA levels of both cytokines were also significantly higher in the HUVEC-C cells subjected to both $20 \mu \mathrm{g} / \mathrm{ml}$ oxLDL treatment and infection with $1 \mathrm{MOI}$ H1N1 PDM2009 virus $(\mathrm{P}<0.05$ and $\mathrm{P}<0.01$, respectively; Fig. 4B and $\mathrm{C}$ ). Therefore, these findings demonstrated the synergistic promotion of pro-inflammatory cytokines in HUVEC-C cells by oxLDL treatment and influenza virus infection.

\section{Discussion}

The mechanism underlining the development of atherosclerosis, which is mediated by oxLDL and infection, is not 

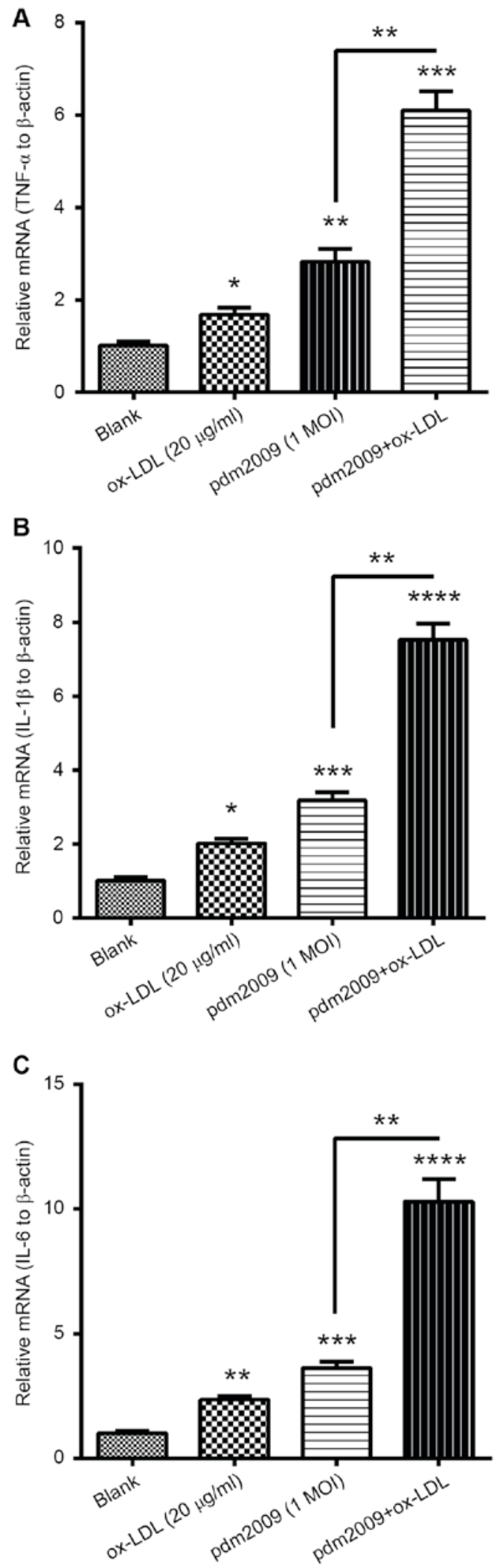

Figure 4. RT-qPCR analysis of pro-inflammatory cytokines in H1N1 PDM2009 virus-infected and oxLDL-treated human endothelial HUVEC-C cells. HUVEC-C cells were treated with $20 \mu \mathrm{g} / \mathrm{ml}$ oxLDL and/or infected with 1 MOI H1N1 PDM2009 virus for $12 \mathrm{~h}$. Subsequently, RT-qPCR was performed to quantify the mRNA levels of (A) TNF- $\alpha$, (B) IL-1 $\beta$ and (C) IL-6. Data are expressed as the mean \pm standard deviation of experiments independently repeated in triplicate. ${ }^{*} \mathrm{P}<0.05,{ }^{* *} \mathrm{P}<0.01,{ }^{* * *} \mathrm{P}<0.001$ and ${ }^{* * * *} \mathrm{P}<0.0001$ vs. blank. RT-qPCR, reverse transcription-quantitative polymerase chain reaction; HUVEC, human umbilical vein endothelial cells; oxLDL, oxidized low density lipoprotein; MOI, multiplicity of infection; TNF, tumor necrosis factor; IL, interleukin. well-documented. oxLDL-, free radical-, or infection-induced inflammatory responses have been demonstrated to lead to endothelial dysfunction (30), and thus may contribute to atherosclerosis. In the present study, we demonstrated the promotion to MMP-9 expression by ox-LDL treatment in HUVEC-C cells. oxLDL treatment significantly promoted mRNA and protein levels of MMP-9 in the in vitro-cultured HUVEC-C cells dose-dependently and time-dependently. MMP-9 activity was also markedly promoted by oxLDL treatment in HUVEC-C cells. Previous in vivo results also demonstrated MMP-9 overexpression in human progressive atherosclerotic plaques (9); and high levels of MMP-9 have been associated with an increased risk of severe atherosclerosis and unstable plaques in atherosclerotic patients (31). The present study also demonstrated that H1N1 PDM2009 influenza virus infected and replicated efficiently in HUVEC-C cells and the H1N1 PDM2009 virus infection synergistically enhanced the oxLDL-promoted MMP-9 levels in HUVEC-C cells. Therefore, we propose that the promotion of MMP-9 by oxLDL underlines oxLDL-induced atherosclerosis.

Inflammation involves the development of atherosclerosis both via mediating the effects of above-mentioned risk factors (ox-LDL and infection) and by directly affecting the vessel wall $(32)$. The vascular inflammation $(23,24)$ impairs the vascularity and causes endothelial cell dysfunction. A previous mice model study indicated that influenza virus directly infects, and resides in atherosclerotic arteries, in association with systemic and arterial-level pro-inflammatory changes (33). Influenza virus infection-induced autoimmune mechanisms have also been shown to participate in athermanous lesions (34). Our study findings indicated that H1N1 PDM2009 virus infection synergistically promotes pro-inflammatory cytokines with oxLDL in HUVEC-C cells. mRNA levels of TNF- $\alpha$, IL-1 $\beta$ and IL- 6 were markedly and synergistically promoted by treatment with $20 \mu \mathrm{g} / \mathrm{ml}$ oxLDL and infection with $1 \mathrm{MOI}$ H1N1 PDM2009 virus.

A previous study demonstrated that influenza virus aggravates the ox-LDL-induced apoptosis of human endothelial cells by promoting p53 signaling (35). Infection with A/Porto Rico/8/1934 (H1N1) (PR8) influenza virus in human endothelial EA.hy926 cells induced apoptosis, which was aggravated by ox-LDL treatment. p53 signaling was also synergistically activated by both influenza virus infection and oxLDL treatment. Our study expanded the current understanding of the synergistical regulation by both oxLDL treatment and influenza virus infection in human endothelial cells.

In conclusion, the present study is the first to demonstrate the synergistical promotion of the expression of MMP-9 and pro-inflammatory cytokines in human endothelial HUVEC-C cells. Such synergistical promotion may contribute to influenza virus infection and oxLDL-mediated endothelial dysfunction.

\section{References}

1. Ehara S, Ueda M, Naruko T, Haze K, Itoh A, Otsuka M, Komatsu R, Matsuo T, Itabe H and Takano T: Elevated levels of oxidized low density lipoprotein show a positive relationship with the severity of acute coronary syndromes. Circulation 103: 1955-1960, 2001.

2. Verhoye E and Langlois; Asklepios Investigators: Circulating oxidized low-density lipoprotein: A biomarker of atherosclerosis and cardiovascular risk? Clin Chem Lab Med 47: 128-137, 2009. 
3. Itabe H: Oxidized low-density lipoprotein as a biomarker of in vivo oxidative stress: From atherosclerosis to periodontitis. J Clin Biochem Nutr 51: 1-8, 2012.

4. Imanishi T, Hano T, Sawamura T, Takarada S and Nishio I Oxidized low density lipoprotein potentiation of Fas-induced apoptosis through lectin-like oxidized-low density lipoprotein receptor-1 in human umbilical vascular endothelial cells. Circ J 66: 1060-1064, 2002.

5. Bekkering S, Quintin J, Joosten LA, van der Meer JW, Netea MG and Riksen NP: Oxidized low-density lipoprotein induces long-term proinflammatory cytokine production and foam cell formation via epigenetic reprogramming of monocytes Arterioscler Thromb Vasc Biol 34: 1731-1738, 2014.

6. Chen J, Mehta JL, Haider N, Zhang X, Narula J and Li D: Role of caspases in Ox-LDL-induced apoptotic cascade in human coronary artery endothelial cells. Circ Res 94: 370-376, 2004.

7. Galis ZS, Sukhova GK, Lark MW and Libby P: Increased expression of matrix metalloproteinases and matrix degrading activity in vulnerable regions of human atherosclerotic plaques. J Clin Invest 94: 2493-2503, 1994.

8. Falk E, Shah PK and Fuster V: Coronary plaque disruption. Circulation 92: 657-671, 1995.

9. Galis ZS and Khatri JJ: Matrix metalloproteinases in vascular remodeling and atherogenesis: The good, the bad and the ugly. Circ Res 90: 251-262, 2002.

10. Visse R and Nagase H: Matrix metalloproteinases and tissue inhibitors of metalloproteinases: Structure, function and biochemistry. Circ Res 92: 827-839, 2003.

11. Kuzuya M and Iguchi A: Role of matrix metalloproteinases in vascular remodeling. J Atheroscler Thromb 10: 275-282, 2003.

12. Flamant M, Placier S, Dubroca C, Esposito B, Lopes I, Chatziantoniou C, Tedgui A, Dussaule JC and Lehoux S: Role of matrix metalloproteinases in early hypertensive vascular remodeling. Hypertension 50: 212-218, 2007.

13. Sukhova GK, Schonbeck U, Rabkin E, Schoen FJ, Poole AR, Billinghurst RC and Libby P: Evidence for increased collagenolysis by interstitial collagenases- 1 and -3 in vulnerable human atheromatous plaques. Circulation 99: 2503-2509, 1999.

14. Herman MP, Sukhova GK, Libby P, Gerdes N, Tang N, Horton DB, Kilbride M, Breitbart RE, Chun M and Schönbeck U: Expression of neutrophil collagenase (matrix metalloproteinase-8) in human atheroma: A novel collagenolytic pathway suggested by transcriptional profiling. Circulation 104: 1899-1904, 2001.

15. Nikkari ST, O'Brien KD, Ferguson M, Hatsukami T, Welgus HG, Alpers CE and Clowes AW: Interstitial collagenase (MMP-1) expression in human carotid atherosclerosis. Circulation 92: 1393-1398, 1995

16. Rajavashisth TB, Xu XP, Jovinge S, Meisel S, Xu XO, Chai NN, Fishbein MC, Kaul S, Cercek B, Sharifi B and Shah PK: Membrane type 1 matrix metalloproteinase expression in human atherosclerotic plaques: Evidence for activation by proinflammatory mediators. Circulation 99: 3103-3109, 1999.

17. Xu XP, Meisel SR, Ong JM, Kaul S, Cercek B, Rajavashisth TB, Sharifi B and Shah PK: Oxidized low-density lipoprotein regulates matrix metalloproteinase- 9 and its tissue inhibitor in human monocyte-derived macrophages. Circulation 99: 993-998, 1999.

18. Roivainen M, Viik-Kajander M, Palosuo T, Toivanen P, Leinonen M, Saikku P, Tenkanen L, Manninen V, Hovi T and Mänttäri M: Infections, inflammation and the risk of coronary heart disease. Circulation 101: 252-257, 2000
19. Ravnskov U and McCully KS: Infections may be causal in the pathogenesis of atherosclerosis. Am J Med Sci 344: 391-394, 2012.

20. Hechter RC, Budoff M, Hodis HN, Rinaldo CR, Jenkins FJ, Jacobson LP, Kingsley LA, Taiwo B, Post WS, Margolick JB and Detels R: Herpes simplex virus type 2 (HSV-2) as a coronary atherosclerosis risk factor in HIV-infected men: Multicenter AIDS cohort study. Atherosclerosis 223: 433-436, 2012.

21. Gurevich VS, Pleskov VM, Levaia MV, Bannikov AI, Mitrofanova LB and Urazgil'Deeva SA: Influenza virus infection in progressing atherosclerosis. Kardiologiia 42: 21-24, 2002.

22. Auer J, Berent R, Weber T and Eber B: Influenza virus infection, infectious burden and atherosclerosis. Stroke 33: 1454-1455, 2002.

23. Streblow DN, Orloff SL and Nelson JA: Do pathogens accelerate atherosclerosis? J Nutr 131: 2798S-2804S, 2001.

24. Söderberg-Nauclér C: Does cytomegalovirus play a causative role in the development of various inflammatory diseases and cancer? J Intern Med 259: 219-246, 2006.

25. Epstein SE, Zhou YF and Zhu J: Infection and atherosclerosis: Emerging mechanistic paradigms. Circulation 100: e20-e28, 1999.

26. Libby P, Ridker PM and Maseri A: Inflammation and atherosclerosis. Circulation 105: 1135-1143, 2002.

27. Nieto FJ, Adam E, Sorlie P, Farzadegan H, Melnick JL, Comstock GW and Szklo M: Cohort study of cytomegalovirus infection as a risk factor for carotid intimal-medial thickening, a measure of subclinical atherosclerosis. Circulation 94: 922-927, 1996.

28. Smieja M, Gnarpe J, Lonn E, Gnarpe H, Olsson G, Yi Q, Dzavik V, McQueen M and Yusuf S; Heart Outcomes Prevention Evaluation (HOPE) Study Investigators: Multiple infections and subsequent cardiovascular events in the heart outcomes prevention evaluation (HOPE) study. Circulation 107: 251-257, 2003.

29. Celik S, Shankar V, Richter A, Hippe HJ, Akhavanpoor M, Bea F, Erbel C, Urban S, Blank N, Wambsganss N and Katus HA: Proinflammatory and prothrombotic effects on human vascular endothelial cells of immune-cell-derived light. Eur J Med Res 14: 147-156, 2009.

30. Livak KJ and Schmittgen TD: Analysis of relative gene expression data using real-time quantitative PCR and the 2(-Delta Delta C(T)) method. Methods 25: 402-408, 2001.

31. Halade GV, Jin YF and Lindsey ML: Matrix metalloproteinase (MMP)-9: A proximal biomarker for cardiac remodeling and a distal biomarker for inflammation. Pharmacol Ther 139: 32-40, 2013.

32. Gao X, Xu X, Belmadani S, Park Y, Tang Z, Feldman AM, Chilian WM and Zhang C: TNF-alpha contributes to endothelial dysfunction by upregulating arginase in ischemia/reperfusion injury. Arterioscler Thromb Vasc Biol 27: 1269-1275, 2007

33. Haidari M, Wyde PR, Litovsky S, Vela D, Ali M, Casscells SW and Madjid M: Influenza virus directly infects, inflames and resides in the arteries of atherosclerotic and normal mice. Atherosclerosis 208: 90-96, 2010

34. Gurevich VS: Influenza, autoimmunity and atherogenesis. Autoimmun Rev 4: 101-105, 2005.

35. Suo J, Zhao L, Wang J, Zhu Z, Zhang $H$ and Gao R: Influenza virus aggravates the ox-LDL-induced apoptosis of human endothelial cells via promoting p53 signaling. J Med Virol 87: 1113-1123, 2015. 